\title{
Når du blir syk i ferien
}

1. juli 2014 ble ferieloven endret. Endringene innebærer blant annet at en arbeidstaker som blir syk i løpet av ferien, allerede fra første sykedag kan kreve å få sykedagen(e) som ny ferie senere.

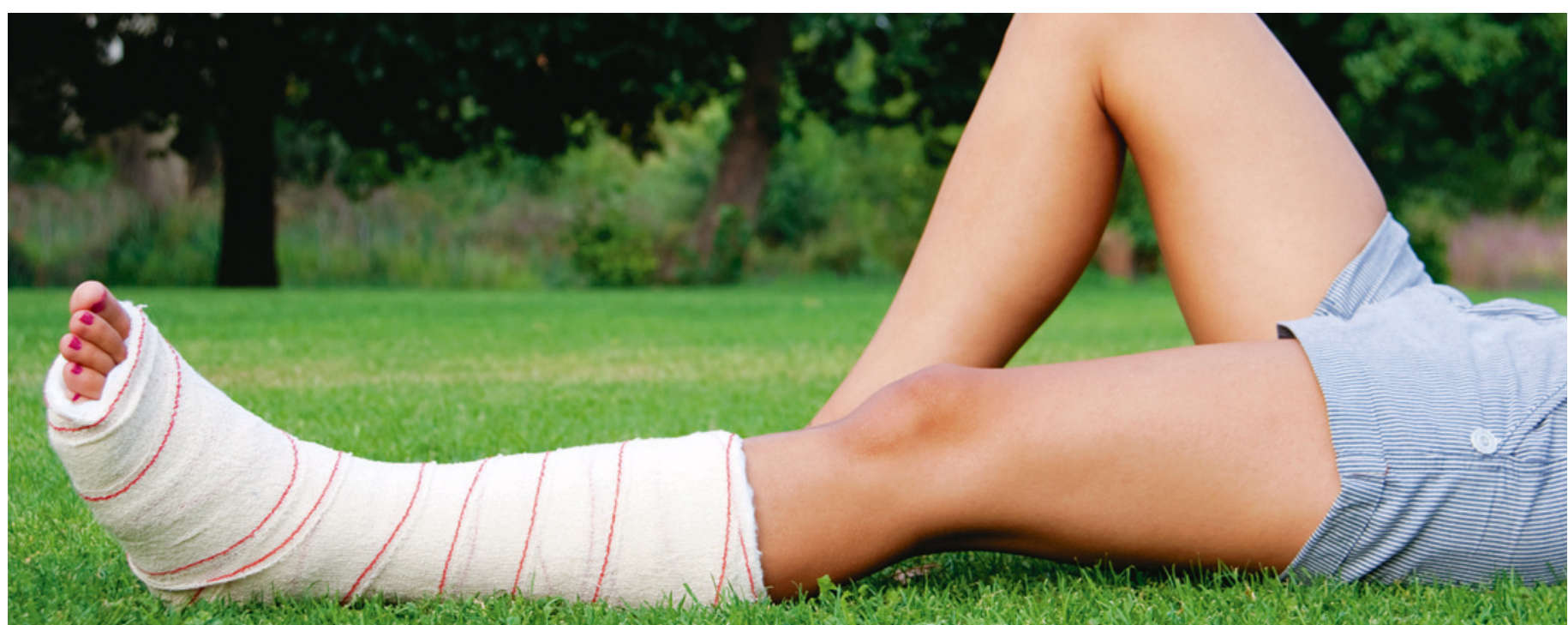

Syk i ferien. Illustrasjonsfoto: Thinkstock

Tidligere var det et vilkår at en arbeidstaker som ble syk i ferien, måtte være syk i en uke for å ha rett til å få ferien utsatt til senere. Etter endringene har man altså rett til å få sykedagen(e) - allerede fra første sykedag - som ny ferie senere. Vilkåret er dog at man er $100 \%$ sykmeldt. Det stilles fremdeles krav til at arbeidsuførheten dokumenteres med legeerklæring.

\section{Legeerklæring}

- Hvis man blir syk før ferien, må kravet om utsatt ferie fremsettes senest siste arbeidsdag man skulle hatt før ferien. Dersom man blir syk i løpet av ferien, må kravet om utsatt ferie fremsettes uten såkalt ugrunnet opphold etter at arbeidet er gjenopptatt, sier Liv Marit Fagerli, advokatfullmektig i Legeforeningen.

\section{Rett til å overføre ferie}

Før endringene var det et tak på hvor mye ferie man hadde krav på å overføre dersom ferien ikke var avviklet på grunn av sykdom eller foreldrepermisjon. Dette er nå endret. Etter endringene har arbeidstaker rett til å overføre all ferie som ikke er avviklet på grunn av sykdom eller foreldrepermisjon. I tillegg har arbeidstaker rett til å overføre annen ferie som i strid med ferielovens bestemmelser ikke er avviklet.

- Hovedregelen er at alle arbeidstakere har rett og plikt til å avvikle full ferie. Det er arbeidsgivers plikt å legge til rette slik at full ferieavvikling blir mulig. Dersom det likevel ikke har vært mulig å få til, sier de nye reglene at det nå ikke er noen begrensninger i hvor mye ferie du kan overføre til neste ferieår. Dersom manglende ferieavvikling skyldes arbeidsgiver, kan arbeidstaker i tillegg til overføring kreve erstatning for økonomisk tap og en rimelig erstatning for velferdstap, sier Fagerli.

\section{Skriftlig avtale er lurt}

Det kan være lurt å inngå en skriftlig avtale med arbeidsgiver, slik at du sikrer at all ferien din blir overført.

Retten til å overføre ferie gjelder også dersom du har vært syk over flere år og av den grunn har mye ferie til gode. Ferien må imidlertid tas ut i feriedager, ikke i penger. Muligheten til å få erstattet ferien økonomisk ved sykdom eller foreldrepermisjon er dermed fjernet. Ferieloven $\S 11$ om utbetaling av feriepenger ved arbeidsforholdets opphør er ikke endret.

- Det betyr at ved opphør av arbeidsforholdet, skal alle opptjente feriepenger utbetales siste vanlige lønningsdag før fratreden, sier Fagerli.

\section{Eline Feiring}

Tidsskriftet
«Hovedregelen er at alle arbeidstakere har rett og plikt til å avvikle full ferie»

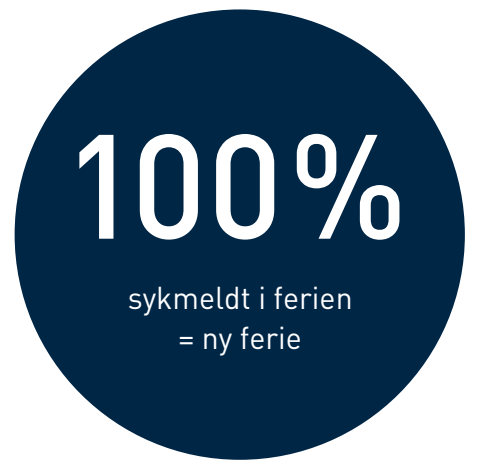

